Jurnal Teknologi, 54 (Sains Sosial), Jan. 2011: 51-63

(C) Universiti Teknologi Malaysia

\title{
MATHEMATICS AND SCIENCE PERFORMANCE OF PERSIAN AND NON-PERSIAN LANGUAGE STUDENTS
}

\author{
EBRAHIM MOHAMMADPOUR ${ }^{1}$, MOHAMED NAJIB ABDUL \\ GHAFAR $^{2} \&$ ROHANI OTHMAN ${ }^{3}$
}

\begin{abstract}
This study examined mathematics and science performance of students who frequently, sometimes or never spoke Persian at home. The data were obtained from 1914 Iranian fourth-grade students who participated in TIMSS 2003. One-way ANOVA and KruskalWallis statistical tests were used to analyze the data. The results showed mathematics and science performance differs significantly among students who frequently, sometimes or never spoke Persian at home. Students who frequently spoke Persian achieved higher scores in both subjects than those who sometimes or never spoke the language at home. In addition, students who sometimes spoke Persian achieved higher scores in both subjects than those who never spoke it. Furthermore, the results indicated that having access to home educational resources, doing homework on mathematics and science, students' self-confidence in learning mathematics and science were significantly different among the three groups and the differences were in favour of students who frequently and sometimes spoke Persian respectively.
\end{abstract}

Keywords: Mathematics; performance; Persian; science; students; TIMSS

\subsection{INTRODUCTION}

The purpose of formal education in any country is to provide for learning. Educational systems try to provide an environment where students learn as much as possible using the best possible means and resources. Learning is a complex activity and it is affected by various factors, such as aptitude, attitudes, gender, motivation, language, learning styles and strategies. There are also factors such as the subject matter, teaching methods and family background which are dependent on situations in which the students are exposed to in the study environment. Language acquisition is one of the influential factors which determine students' academic performance. The world, consists of people of different races, cultures,

Faculty of Education, Universiti Teknologi Malaysia, 81310, UTM Johor Bahru, Johor Darul Ta'azim, Malaysia 
Languages and tribes. In other words, multi-cultural and multi-lingual are characteristics of the present societies and researchers have indicated that approximately $60 \%$ of the world's populations are either bilingual or multilingual (Parvanehnezhad \& Clarkson, 2008).

Iran is a multilingual country where its people use or speak Persian as the official language of instruction in all levels of education throughout the country. According to Trends in International Mathematics and Science Study (TIMSS) 2003 about 34\% of Iranian students either sometimes or never spoke Persian at home. There are other main languages in Iran such as Turkish, Kurdish, Lori, Urdu and Arabic. However, the curriculum and textbooks issued by the Ministry of Education at all levels of education from grade 1 to grade 12 are in Persian and all other languages were ignored as the official instruction in schools (Karimi \& Bakhshalizadeh, 2008). Using only Persian as the medium of instruction in schools has created the problem of bilingualism at homes and schools for millions of the non-Persian speaking children (Hameedy, 2004).

\subsection{LITERATURE REVIEW}

Research findings on the impact of language on students' academic performance can be divided into two parts. Some studies (Azina Ismail \& Awang, 2007; Cummins, 1981, 1996, Goodz, 1994, cited in Clark, 2000) indicated that bilingualism does not show any deterioration on students' academic performance. In contrast, there are several studies (e.g., Abedi, Courtney, Leon, \& Goldberg, 2005; Clarkson, 2006; Garcia \& Gopal, 2003; Hameedy, 2004; Howie, 2004; Kenyon \& Alvin, 1982; Kiamanesh, 2000; Levin \& Shohamy, 2008; Prophet \& Badede, 2006; Stranda \& Demieb, 2005) that have shown bilingualism is an important factor that can influence students' academic performance negatively.

TIMSS reports showed that students from homes which frequently use the language of instruction achieved higher scores in mathematics and science than students from homes which spoke it less frequently. Lamb \& Fullarton (2001) reported that American and Australian $8^{\text {th }}$ grade students from non-English speaking backgrounds tend to have lower scores in mathematics achievement than those from English-speaking backgrounds. Similar findings were found by Howie (2004) in exploring the effects of language proficiency on students' performance among South African $8^{\text {th }}$ grade students. She concluded that, students from homes where 'always' or 'almost always' spoke the language of the test, achieved more than 140 scores than students who never spoke it. Kiamanesh (2000) indicated that there was a significant difference between the average performance of students who spoke Persian at home than those who did not. He added that speaking Persian was the most effective factor on students' academic performance after 
students' attitude. Another study examined the performance of Iranian students based on Progress International Reading Literacy Study (PIRLS) 2001 and it was concluded that there was a significant difference in reading performance between Persian and non-Persian speaking students and that Persian speaking students achieved higher scores than the non-Persian speaking students (Hameedy, 2004).

In contrast, another research showed that Malaysian eight-grade students who frequently spoke Bahasa Malaysia which is the medium of the instruction in Malaysian schools, achieved lower scores as compared to those who spoke it less frequently (Azina Ismail \& Halimah Awang,2007).

\subsection{OBJECTIVE OF THE STUDY}

This study was designed to address the following objectives:

(1) To find out the differences or similarities in mathematics performance among students who frequently spoke Persian and those who less frequently or never spoke it.

(2) To find out the differences or similarities in science performance among students who frequently spoke Persian and those who less frequently or never spoke it.

\subsection{METHODOLOGY}

The data for the study was obtained from the Trends in International Mathematics and Science Study (TIMSS). A total of 4352 Iranian fourth-grade students participated in TIMSS 2003. Based on the students' responses to the question "How often do you speak the language of test at home?". The results showed 2541 students reported that they 'always' spoke Persian at home, 311 'almost always', 758'sometimes' and 638 'never'. Only 77 students did not respond to the question.

First, two adjacent groups of students were formed. The first group consisted of those who responded with 'always' and 'almost always' spoke Persian at home $(2541+311=2852)$ to form a group of students who 'frequently' spoke Persian. Next, since the number of students in the earlier group (frequently spoke Persian) were not equal to the number of students who 'sometimes' and spoke Persian (758) and 'never' spoke Persian (638); and to avoid violation of homogeneity of variances which is one of the important assumptions in an analysis of variance, two random samples were selected using the SPSS program from those who 
'sometimes' and 'never' spoke Persian. Consequently, the number of students within all the three groups was equal to 638 .

\subsection{MEASURES}

TIMSS 2003 used mathematics and science tests to assess students' performance and each student had four types of scores. These scores are raw score, standardized score, Rasch score, and a set of plausible values score. Due to a great number of items (313 items, 161 in mathematics and 152 in science) no student sat for the whole test to answer all the items, but rather, each student received only a small sample of the test items which were randomly assembled in different booklets (Martin, Mullis, \& Chrostowski, 2004). Thus, TIMSS used IRT ${ }^{1}$ scaling to describe students' achievement on the tests (Martin et al., 2004). Based on this scaling, each student was given five plausible values which was the score the students might have obtained in completing the full test. "Plausible values are multiple imputations of the unobservable latent achievement for each student" $(\mathrm{Wu}, 2005)$. In the present study, the means of the five plausible values for mathematics and science separately served as the students' performance score. It is important to note that the differences in the means of the five plausible values were 1.40 and 1.14 for mathematics and science respectively. The differences among plausible values can be served as index of reliability ( $\mathrm{Wu}, 2005)$. Since the differences among the means of plausible values were small it can be conclude that the plausible values would be reliable. In addition, to describe students' background among the three comparison groups based on their correlations with mathematics and science performance as well as previous studies, a number of variables were selected from the Students Questionnaire for further analysis (Tables 3 and 4).

\subsection{DATA ANALYSIS}

One-way ANOVA was used to examine differences in mean scores of mathematics and science among students who frequently, sometimes and never spoke Persian. The same analysis was used to assess the differences in students' self-confidence in learning mathematics and science. The Fisher's LSD (Least

\footnotetext{
${ }^{1}$ - Item Response Theory is a theory in testing situations suppose that examinee performance on a test can be predicted by defining examinee characteristics referred to as trait or ability estimating scores for examinees on these traits and using the scores to predict or explain item and test performance(Hambleton \& Swaminathan, 1985).
} 
Significant Difference) test was utilized for post-hoc analysis. The Kruskal-wallis was used to examine differences in home educational resources and homework on mathematics and science among the mentioned three groups.

\subsection{RESULTS}

The results of the One-way ANOVA to examine the differences in mathematics performance among the three groups are presented in Table 1.

Table 1 ANOVA to assess the differences in Mathematics performance

\begin{tabular}{|c|c|c|c|c|c|c|c|c|c|}
\hline Groups & $\mathbf{N}$ & Mean & S.D & $\begin{array}{l}\text { Std. } \\
\text { Error }\end{array}$ & $\begin{array}{l}\text { ANOV } \\
\text { A }\end{array}$ & df & $\begin{array}{l}\text { Mean } \\
\text { Square }\end{array}$ & $\mathbf{F}$ & Sig \\
\hline $\begin{array}{l}\text { Frequently } \\
\text { spoke Persian }\end{array}$ & 638 & 434.81 & 83.43 & 3.30 & $\begin{array}{l}\text { Between } \\
\text { Groups }\end{array}$ & 2 & 915551.60 & \multirow{4}{*}{146.16} & \multirow{4}{*}{.001} \\
\hline $\begin{array}{l}\text { Sometimes } \\
\text { spoke Persian }\end{array}$ & 638 & 388.18 & 78.80 & 3.12 & $\begin{array}{l}\text { Within } \\
\text { Groups }\end{array}$ & $\begin{array}{l}191 \\
1\end{array}$ & 6264.5 & & \\
\hline $\begin{array}{l}\text { Never spoke } \\
\text { Persian }\end{array}$ & 638 & 359.78 & 74.98 & 2.97 & & & & & \\
\hline Total & 1914 & 394.26 & 84.94 & 1.94 & & & & & \\
\hline
\end{tabular}

Table 1 shows that the mathematics performance differs significantly among students who frequently, sometimes and never spoke Persian, F $(2,1911)=$ $146.16, \mathrm{p}<0.001$. The results of the LSD test indicated that the differences among the means scores of mathematics performance of the three groups were significant $(\mathrm{p}<0.001)$ and the differences were in favour of those students who frequently and sometimes spoke Persian respectively. As presented in Table 1 students who frequently spoke Persian achieved 46.63(434.81-388.18) and 75 (434.81-359.78) scores in mathematics higher than those who sometimes and never spoke Persian respectively. Besides, students who sometimes spoke Persian performed higher than students who never spoke Persian by 28.4 (388.18-359.78) score.

The results of the One-way ANOVA to examine the differences in science performance among the three groups are presented in Table 2. 
Table 2 ANOVA to assess the differences in Science performance

\begin{tabular}{|c|c|c|c|c|c|c|c|c|c|}
\hline Groups & $\mathbf{N}$ & Mean & S.D & $\begin{array}{l}\text { Std. } \\
\text { Error }\end{array}$ & $\begin{array}{l}\text { ANOV } \\
\text { A }\end{array}$ & df & $\begin{array}{l}\text { Mean } \\
\text { Square }\end{array}$ & $\mathbf{F}$ & Sig \\
\hline $\begin{array}{l}\text { Frequently } \\
\text { spoke Persian }\end{array}$ & 638 & 465.55 & 86.31 & 3.42 & $\begin{array}{l}\text { Between } \\
\text { Groups }\end{array}$ & 2 & 1247181.44 & \multirow{4}{*}{169.12} & \multirow{4}{*}{.001} \\
\hline $\begin{array}{l}\text { Sometimes } \\
\text { spoke Persian }\end{array}$ & 638 & 414.83 & 83.59 & 3.31 & $\begin{array}{l}\text { Within } \\
\text { Groups }\end{array}$ & 1911 & 6264.5 & & \\
\hline $\begin{array}{l}\text { Never spoke } \\
\text { Persian }\end{array}$ & 638 & 87 & 74.68 & 3.47 & & & & & \\
\hline Total & 1914 & 419.28 & 93.11 & 2.13 & & & & & \\
\hline
\end{tabular}

Table 2 indicates that the differences among science performance for the four groups were significant, $\mathrm{F}(2,1911)=169.12$, $\mathrm{p}<0.001$. The results of the LSD test indicated that the differences among the means scores of science achievements of the three groups were significant $(p<0.001)$ and the differences were in favour of those students who frequently and sometimes spoke Persian respectively. Students who frequently spoke Persian achieved 50.72 and 88 scores higher in science than those who sometimes and never spoke Persian respectively. Also, students who sometimes spoke Persian performed higher than students who never spoke Persian by 37.37 score.

The results of Chi-Square to examine the differences in home educational resources among the three groups are presented in Table 3.

Table 3 shows that the use of home educational resources such as calculator, computer, study desk, and dictionary differ significantly $(\mathrm{p}<0.001)$ among students who frequently, sometimes and never spoke Persian at home. It showed that the lowest mean ranks in all the four home educational resources were among students who frequently spoke Persian. In addition, the percentages showed that the accessibility to the home educational resources among students who frequently spoke Persian was higher than those who sometimes and never spoke Persian. It was followed by students who sometimes spoke Persian at home. The same was true for the number of books students have at home, $\chi^{2}(2)=125.15, p<0.001$. Both the mean ranks and the percentages show that students who never spoke Persian are behind those who are in the other groups. 
Table 3 Students' home educational resources

\begin{tabular}{|c|c|c|c|c|c|}
\hline \multirow[t]{2}{*}{ Factors } & Questions & \multirow[t]{2}{*}{ Responses } & \multicolumn{3}{|c|}{ spoke Persian at home } \\
\hline & $\begin{array}{l}\text { Do you have any of these items at } \\
\text { your home? TIMSS coding } \\
\text { remained based on a two point scale: } \\
1=\text { Yes; } 2=\text { No }\end{array}$ & & Frequently & Sometimes & Never \\
\hline \multirow{22}{*}{$\begin{array}{c}\text { Home } \\
\text { educational } \\
\text { resources }\end{array}$} & \multirow[t]{6}{*}{ Calculator } & Yes & 79.6 & 68.3 & 61.0 \\
\hline & & No & 15.2 & 22.6 & 32.3 \\
\hline & & Total & 94.8 & 90.9 & 93.3 \\
\hline & & Missing & 5.2 & 9.1 & 6.7 \\
\hline & & Mean Rank & 863.37 & 975.20 & 1033.93 \\
\hline & & \multicolumn{4}{|c|}{$\chi^{2}(2)=48.32, p<0.001$} \\
\hline & \multirow[t]{6}{*}{ Computer } & Yes & 38.4 & 25.5 & 16.9 \\
\hline & & No & 55.3 & 65.8 & 71.6 \\
\hline & & Total & 93.7 & 91.4 & 88.6 \\
\hline & & Missing & 6.3 & 8.6 & 11.4 \\
\hline & & Mean Rank & 840.08 & 968.72 & 1063.70 \\
\hline & & \multicolumn{4}{|c|}{$\chi^{2}(2)=73.66, p<0.001$} \\
\hline & \multirow[t]{6}{*}{ Study desk } & Yes & 60.3 & 37.8 & 26.6 \\
\hline & & No & 36.7 & 54.9 & 66.6 \\
\hline & & Total & 97.0 & 92.6 & 93.3 \\
\hline & & Missing & 3.0 & 7.4 & 6.7 \\
\hline & & Mean Rank & 773.04 & 1001.27 & 1098.20 \\
\hline & & \multicolumn{4}{|c|}{$\chi^{2}(2)=149, p<0.001$} \\
\hline & \multirow[t]{4}{*}{ Dictionary } & Yes & 52.0 & 33.7 & 18.3 \\
\hline & & No & 43.3 & 59.9 & 74.1 \\
\hline & & Total & 95.3 & 93.6 & 92.5 \\
\hline & & Missing & 4.7 & 6.4 & 7.5 \\
\hline
\end{tabular}




\begin{tabular}{|c|c|c|c|c|c|}
\hline & & Mean Rank & 792.35 & 967.72 & 1112.43 \\
\hline & & \multicolumn{4}{|c|}{$\chi^{2}(2)=142.78, p<0.001$} \\
\hline \multirow[t]{10}{*}{$\begin{array}{l}\text { Books in the } \\
\text { home }\end{array}$} & \multicolumn{2}{|c|}{$\begin{array}{l}\text { About how many books are there in your home? } \\
\text { TIMSS coding remained based on answers to the } \\
\text { above item }\end{array}$} & Frequently & Sometimes & Never \\
\hline & \multicolumn{2}{|l|}{$1=$ None or very few $(0-10$ books $)$} & 32.0 & 49.7 & 64.7 \\
\hline & \multicolumn{2}{|l|}{$2=$ One shelf (11-25 books) } & 22.7 & 21.2 & 15.0 \\
\hline & \multicolumn{2}{|l|}{$3=$ One bookcase (26-100 books) } & 19.7 & 12.5 & 7.4 \\
\hline & \multicolumn{2}{|l|}{$4=$ Two bookcases (101-200 books) } & 7.4 & 3.8 & 3.3 \\
\hline & \multicolumn{2}{|c|}{$5=$ Three or more bookcases (more than 200 books } & 13.3 & 4.2 & 2.8 \\
\hline & \multicolumn{2}{|l|}{ Total } & 95.1 & 91.4 & 93.3 \\
\hline & \multicolumn{2}{|l|}{ Missing } & 4.9 & 8.6 & 6.7 \\
\hline & \multicolumn{2}{|l|}{ Mean Rank } & 1126.07 & 942.83 & 803.60 \\
\hline & \multicolumn{5}{|l|}{$\chi^{2}(2)=125.15, \mathrm{p}<0.001$} \\
\hline
\end{tabular}


Table 4 Time on Mathematics and Science homework and students' self-confidence

\begin{tabular}{|c|c|c|c|c|c|}
\hline Factors & Scale & \multirow{2}{*}{$\begin{array}{l}\text { Response } \\
\text { s }\end{array}$} & \multicolumn{3}{|c|}{ spoke Persian at home } \\
\hline \multirow{7}{*}{$\begin{array}{l}\text { Homework } \\
\text { on } \\
\text { mathematics }\end{array}$} & $\begin{array}{l}\text { How often does your teacher give you homework in } \\
\text { mathematics? }\end{array}$ & & Frequently & $\begin{array}{l}\text { Sometime } \\
\mathrm{s}\end{array}$ & Never \\
\hline & \multirow{5}{*}{$\begin{array}{l}\text { TIMSS coding remained based on a } 5 \text { point scale: } 1=\text { Every } \\
\text { day; } 2=3 \text { or } 4 \text { times a week; } 3=1 \text { or } 2 \text { times a week; } 4=\text { Less } \\
\text { than once a week; } 5=\text { Never. The categories made based } \\
\text { on: High, students who responded that they are given } \\
\text { mathematics homework at least } 3 \text { or } 4 \text { times a week; Low, } \\
\text { students who responded that they are given homework at } \\
\text { most } 1 \text { or } 2 \text { times a week, and Medium, all other } \\
\text { combinations. }\end{array}$} & High & 29.0 & 26.3 & 21.0 \\
\hline & & Medium & 52.4 & 46.4 & 48.7 \\
\hline & & Low & 11.8 & 16.6 & 18.3 \\
\hline & & Total & 93.1 & 89.3 & 88.1 \\
\hline & & Missing & 6.9 & 10.7 & 11.9 \\
\hline & \multicolumn{5}{|c|}{$\chi^{2}(2)=130.44, p<0.001$} \\
\hline \multirow[t]{7}{*}{$\begin{array}{l}\text { Homework } \\
\text { on science }\end{array}$} & $\begin{array}{l}\text { How often does your teacher give you homework in } \\
\text { science? }\end{array}$ & Responses & Frequently & $\begin{array}{l}\text { Sometime } \\
\mathrm{s}\end{array}$ & Never \\
\hline & \multirow{5}{*}{$\begin{array}{l}\text { TIMSS coding remained based on a } 5 \text { point scale: } 1=\text { Every } \\
\text { day; } 2=3 \text { or } 4 \text { times a week; } 3=1 \text { or } 2 \text { times a week; } 4=\text { Less } \\
\text { than once a week; } 5=\text { Never. The categories have been } \\
\text { made the same as mathematics index. }\end{array}$} & High & 8.8 & 11.9 & 8.9 \\
\hline & & Medium & 35.1 & 38.6 & 43.3 \\
\hline & & Low & 47.0 & 37.5 & 38.1 \\
\hline & & Total & 90.9 & 87.9 & 90.3 \\
\hline & & Missing & 9.1 & 12.1 & 9.7 \\
\hline & \multicolumn{5}{|c|}{$\chi^{2}(2)=370.85, p<0.001$} \\
\hline $\begin{array}{l}\text { Mathematics' } \\
\text { self- } \\
\text { confidence }\end{array}$ & \multicolumn{5}{|c|}{$\begin{array}{l}\text { How much do you agree with these statements about learning mathematics? TIMSS coding maintained based } \\
\text { on a 4-point Likert scale: } 1=\text { Agree a lot; } 2=\text { Agree a little; } 3=\text { Disagree a little; } 4=\text { Disagree a lot. (Two items of } \\
\text { Mathematics is more difficult for me and I'm just not good in mathematics reversed coded). This index is based } \\
\text { on the average of responses to the following statements and then it divided into three categories: High, Average } \\
\text { is less than or equal to } 2 \text {; Medium: Average is greater than } 2 \text { and less than } 3 \text {; and Low, Average is greater than or }\end{array}$} \\
\hline
\end{tabular}




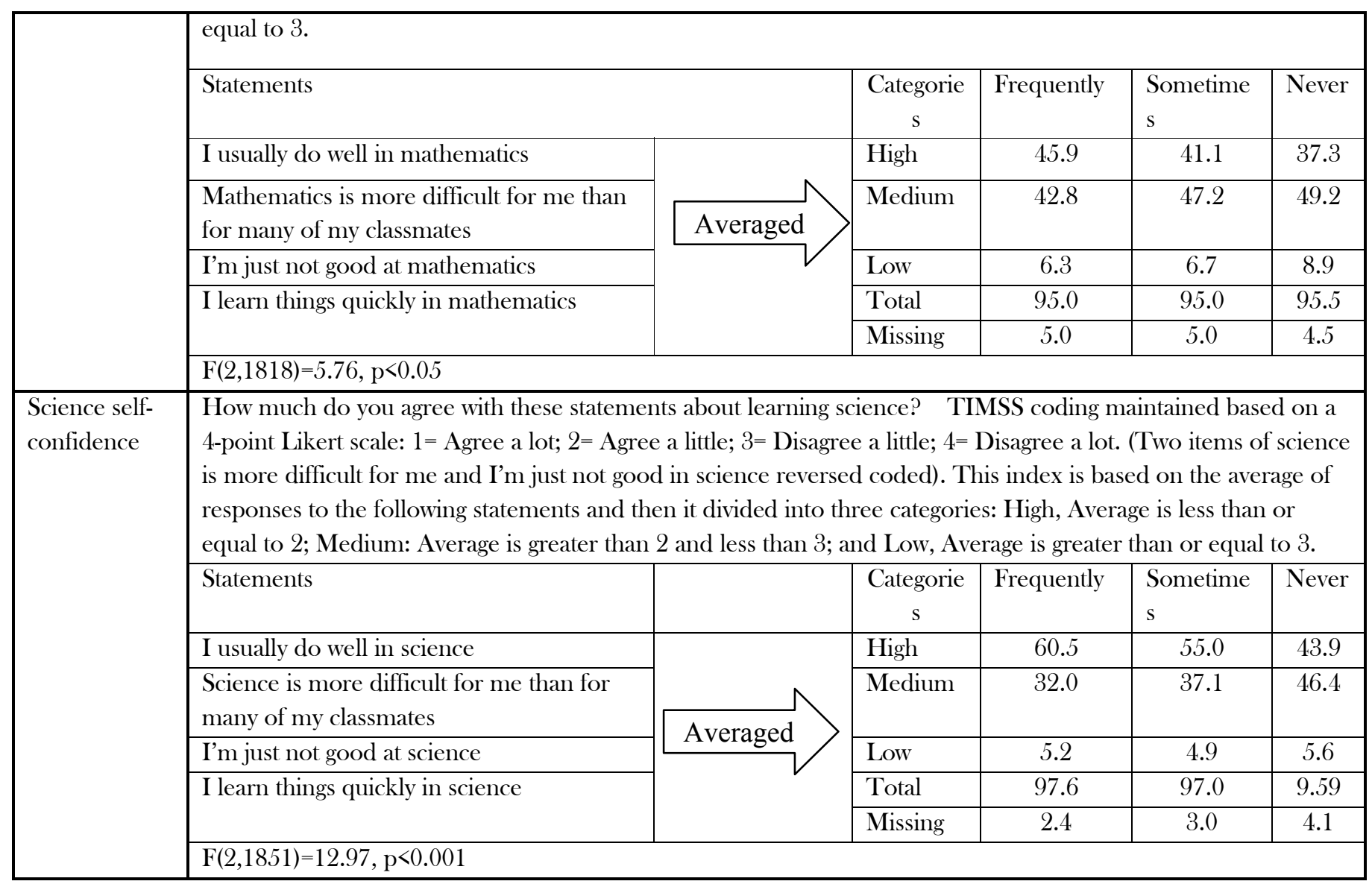


The results of the One-way ANOVA to examine the differences in the time spent to do homework in mathematics and science and self-confidence in learning mathematics and science among the three groups are presented in Table 4.

Table 4 exposes that time spent on mathematics homework is significantly different across the three groups, $\chi^{2}(2)=130.44, p<0.001$. Students who frequently spoke Persian were given more mathematics homework. It was followed by students who sometimes spoke Persian. However, the differences in homework on science among them were statistically significant $\chi^{2}, 2,=370.85$, $\mathrm{p}<0.001)$, which indicated that there were no clear pattern in the differences among the three groups. Students' self-confidence in learning mathematics was statistically different among students who frequently, sometimes and never spoke Persian, F $(2,1818)=5.76, \mathrm{p}<0.05$. Similarly, students' self-confidence in learning science was significantly different, $\mathrm{F}(2,1851)=12.97$, $\mathrm{p}<0.001$. As shown in Table 4 self-confidence in learning mathematics and science was higher among students who frequently spoke Persian and it was followed by those who sometimes spoke it.

\subsection{DISCUSSION AND CONGLUSION}

Bilingualism is a reality in the present society among people of different race, culture and ethnic background living in the same country. As such, it is seen as an important component in any education system. This study was designed to examine mathematics and science performance among students who frequently, sometimes and never spoke Persian at home. The data obtained was based on TIMSS 2003 data sets. The results showed that mathematics and science performances were significantly different among students who frequently, sometimes and never spoke Persian at home and the results were in favour of students who frequently spoke Persian, followed by the students who sometimes. However the differences between mean scores of mathematics and science performance of students who frequently spoke Persian and those who sometime, were far more obvious as compared to students who frequently spoke Persian and those who never. These results confirmed the findings of Kiamanesh, (2000); Hameedy, (2004) in Iran and Howie, (2004) in South Africa.

Home possession of educational resources including calculator, computer, study desk, dictionary and number of books were significantly different among the three groups and the differences were first in favour of students who frequently spoke Persian and secondly students who sometimes do it. Students who frequently spoke Persian were given more mathematics homework than the other two groups, but there was no clear pattern of differences in science homework among the compared groups. Additionally, self-confidence in learning 
mathematics and science were higher among students who frequently spoke Persian than those who sometimes and never do it.

In Iran, the Ministry of Education only offers a one-month (about 100 hours) pre-primary education classes for bilingual children for the purpose of preparing them for primary school and to promote the Persian language. Although, in some parts of the country there are pre-school institutions to offer informal education for children who are 5 years old, however, these institutions are not pervasive throughout the non- Persian speaking regions, particularly in the rural areas. Secondly, another one year training provided by the Ministry is not a formal course in the educational system, so the non-Persian speakers in the rural areas do not have access to this course. On the other hand, according to TIMSS 2003 data, almost $33 \%$ of Iranian fourth-grade students belong to homes where they never or only sometimes spoke Persian. With respect to this proportion of non-Persian speakers and research findings that have shown a positive relationship between students' first language and academic performance (e.g., Hameedy, 2004; Kiamanesh, 2000; Howie, 2004; Kenyon \& Alvin, 1982; Durham \& Farkas, 2007; Garcia \& Gopal, 2003; Strand \& Demie, 2005; Clarkson, 206) the results of this study is expected and measures have to be taken to rectify the problem to promote better students academic performance among non-Persian speaking students especially in remote areas of Iran.

\section{REFERENCES}

Abedi, J., Courtney, M., Leon, S., \& Goldberg, J. 2005. Language Accommodations for English Language Learners in Large Scale Assessments: Bilingual Dictionaries and Linguistic Modification. National Centre for Research on Evaluation, Standards, and Student Testing (CRESST), University of California, Los Angeleso).

Azina Ismail, N., \& Awang, H. 2007. Differences in Mathematics Achievement among Eight-grade Students in Malaysia. International Journal of Science and Mathematics Education. 6: 559-571.

Brisk, M. E., \& Harrington, M. M. 2007. Literacy and Bilingualism: a Handbook for All Teachers Lawrence Erlbaum Associates. 2 ed. London: Mahwah, NJ : Lawrence Erlbaum Associates.

Clarkson, P. C. 2006. Australian Vietnamese Students Learning Mathematics: High Ability Bilinguals and Their Use of Their Language, Educational Studies in Mathematics. Educational Studies in Mathematics. 64: 191-215.

Ellis, E. 2006. Monolingualism: The unmarked case. Estudios de Sociolingrustica. 7: 173-196.

Garcia, P. A., \& Gopal, M. 2003. The Relationship to Achievement on the California High School Exit Exam for Language Minority Students . NABE, Journal of Research and Practice Winter 2003. 123-137.

Hambleton, R., \& Swaminathan, H. 1985. Tem Response Theory : Principles and Applications. Dordrecht: Kluwer Academic Pub.

Hameedy, M. A. 2004. Bilinguality of Home and School in Iran: Conditions and Consequences as Showcased in PIRLS.

Howie, S. 2004. System-level Evaluation: Language and Other Background Factors Affecting Mathematics Achievement Evaluating Students' Achievement. Prospects: An Annual Journal of American Cultural Studies. XXXV.

karimi, A. A., \& Bakhshalizadeh, S. 2008. Ministry of Education of Islamic Republic of Iran. In I. V. S. Mullis, M. O. Martin, J. F. Olson, D. R. Berger, D. Milne \& G. M. Stanco (Eds.). Timss 2007 
Encyclopedia: A Guide to Mathematics and Science Education Around the World (Vol. 1): TIMSS \& PIRLS International Study Center, Lynch School of Education, Boston College.

Kenyon, S. C., \& Alvin, Y. S. 1982. The Impact of Language of Instruction on the Educational Achievement of Hispanic Students. National Centre for Bilingual Research, Los Alamitos, Calif,ERIC,Ed 234641

Kiamanesh, A. R. 2000. Evaluation of Educational Inputs and Outputs for Iranian Students in Fifth Grade: Educational Research Institute for Education, Islamic Republic of Irano. Document Number)

Levin, T., \& Shohamy, E. 2008. Achievement of immigrant students in mathematics and academic Hebrew in Israeli school: A large-scale evaluation study. Studies in Educational Evaluation. 34: 1-14.

Martin, M. O., Mullis, I. V. S., \& Chrostowski, S. J. 2004. TIMSS 2003 Technical Report. TIMSS \& PIRLS International Study Center, Lynch School of Education, Boston College.

Parvanehnezhad, Z., \& Clarkson, P. 2008. Iranian Bilingual Students Reported Use of Language Switching when Doing Mathematics. Mathematics Education Research Journal. 20: 52-81.

Prophet, R. B., \& Badede, N. B. 2006. Language and Student Performance in Junior Secondary Science Examination: The Case of Second Language Learners in Botswana. International Journal of Science and Mathematics Education.

Stranda, S., \& Demieb, F. 2005. English Language Acquisition and Educational Attainment at the End of Primary School. Educational Studies. 13: 275-291.

Thisaphungo Mukhuba, M. 2005. Bilingualism, Language Attitudes, Language Policy and Language Planning: A Sociolinguistic Perspective. Journal of Language and Learning, 3.

Wu, M. 2005. The Role of Plausible Values in Large-Scale Survey. Studies in Educational Evaluation. 31: 114-128. 